DOI https://doi.org/10.18551/rjoas.2017-12.17

\title{
TREND AND DETERMINANTS OF STRUCTURAL TRANSFORMATION IN NIGERIA'S AGRICULTURE SECTOR
}

\author{
Coker Ayodeji Alexander Ajibola* \\ Department of Agricultural Economics and Extension Technology, School of Agriculture and \\ Agricultural Technology, Federal University of Technology, Minna, Nigeria
}

\author{
Alabi Omotayo Olugbenga \\ Department of Agricultural Economics and Extension, Faculty of Agriculture, \\ University of Abuja, Nigeria
}

*E-mail: ayodejicoker@futminna.edu.ng

\begin{abstract}
Recently, transformation from farm to non-farm activities has been associated with numerous developing and under-developed economies of the world. This article therefore explores the trend and determinants of structural transformation in Nigeria's agriculture sector. The study employed secondary data, descriptive and inferential statistics to reach its conclusion. While the trend data reveals a declining and increasing share of the agriculture and service sectors in employment respectively, suggesting a glimpse of transformation, the vector error correction model showed that there were no significant determinants of structural transformation in the agriculture sector among the independent variables in the model; thus raising questions as to whether the transformation trend observed was due to chance. While suggesting further work to ascertain the true nature of transformation and to identify its actual determinants, we recommend increased technological change, specialization, enhanced efficiency and improvement of human capital and institutions within Nigeria's agriculture sector to sustain and fully unearth the transformation process.
\end{abstract}

\section{KEY WORDS}

Structural transformation, agriculture sector, service sector, Nigeria, technological change, efficiency, institutions.

Recent dialogues and literature on transformation in Africa have alluded to the slow pace of structural transformation. Badiane (2013) for instance, established that the Gross Domestic Product and the labour share of Agriculture have barely changed over the last 30 years, with noticeable exceptions, being among the North African Countries and to a lesser extent, Central African countries. Labour productivity in agriculture has also stagnated and declined sharply in the non-agriculture sector, while employment had fallen in agriculture and increased rapidly in the non-agriculture sector, driven by service and less by industry. The contribution of structural change to productivity growth has been mainly negative in most regions of the continent, with the exception of West Africa. This was noted to be negative in more than 40 per cent of Africa in the 80s. Todaro and Smith (2012) also argued that international constraints currently limit the transition of developing countries and that if these countries are exposed to opportunities presented by the industrial countries, such as sources of capital, technology and manufactured inputs, as well as market for export they can make the transition faster than those of the industrialized nations. Nigeria implemented the Structural Adjustment Programme in the mid 80s and 90s and a Transformation Agenda recently (2011-2015) and thus, numerous researchers (Oyelaran-Oyeyinka and Ola-David, 2015 and Ariyo and Olaniyan, 2014) have established that Nigeria is undergoing a structural change, having noted changes in the contributions of key sector to the GDP and employment and changes in the structures of the service and industry sectors. However, in-spite of these developments, its position as the largest economy in Africa and the high growth recorded during 2011-2015, which averaged 4.5 per cent per annum, majority of Nigerians remain 
under the burden of poverty, inequality and unemployment. General economic performance was also seriously undermined by deplorable infrastructure, corruption and mismanagement of public finances (Federal Republic of Nigeria (Economic Recovery and Growth Plan), 2017). This article, therefore examined the trend of employment share of agriculture and selected sectors (industry and services), that is, trend of and determinants of structural transformation in Nigeria's Agriculture Sector. The article questions the existence of structural transformation in Nigeria's agriculture sector, given its backwardness in several development outcomes and thus, hypothesised that agriculture sector, among other economic variables do not drive structural transformation in Nigeria.

\section{LITERATURE REVIEW}

Concepts of Structural Transformation. Mensah et al, (2016) noted that the literature on structural transformation is scanty but growing. Kuznets (1955) for instance took a broader look and thus described structural transformation to mean countries' transitions from developing to developed economy. Contributors lately however have been specific; United Nations Conference on Trade and Development (undated) and Page (2012) for instance, equated structural change (structural transformation) to the movement of labour and other productive resources from low productivity to high productivity economic activities or uses. The source noted that structural transformation can be beneficial to the developing countries because of their peculiar structural heterogeneity, which supports few high productivity activities. United Nations Economic Commission for Africa (2016) also discussed structural change in terms of sectoral compositional changes in output or employment in relation to primary, secondary or tertiary activities as economic development proceeds. It however harped on the need for rigorous appreciation of this concept for strategic policy making on transformational processes beyond the understanding of linear progression.

Theoretical Insights. The theoretical models of structural transformation is coached in the two sector theory of Lewis of the $50 \mathrm{~s}$, which recognised the existence of the traditional rural and a modern urban sector and the transmission of surplus labour from the former to the latter sector. The theory, later modified, formalised and extended by Fei, Ranis, Jorgenson and others (Todaro and Smith, 2012; Norton et al., 2015) has been associated with the recent growth experience of China and labour markets in the other developing countries. The theory is premised on the assumption that the rate of labour transfer and employment creation in the modern sector is proportional to the modern-sector capital formation. Secondly, that surplus labour exists in rural areas while there is full employment in the urban areas and thirdly the notion of a competitive modern sector labour market that guarantees the continued existence of constant real urban wages and lastly, a concern about the occurrence of diminishing returns in the modern industrial sector. However, the best known model of structural change is based largely on the work of Chenery and Colleagues, built on Kuznet's modern economic growth of developed countries. This model identified key characteristic features of development process to include shift from agriculture to industrial production, steady accumulation of physical and human capital, the change in consumer demand to diversified manufactured food, decline in population. The key hypothesis of structural change model is that development is an identifiable process of growth and change whose main feature are similar in all countries. However recently, United Nations Economic Commission for Africa (UNEC) (2016) harped on the need for rigorous appreciation of this concept for strategic policy making on transformational processes beyond the understanding of linear progression.

Structural Transformation in Africa. Employing micro-level data on Uganda, Christiaensen and Kaminski (2015) established heterogeneous and gradual but reversible structural transformation over a five-year period with 13 per cent of population having moved out of agriculture, and an increase in labour market participation. It further affirmed that 60 per cent of micro-level agricultural-non agricultural occupational transformation occurred through non-farm enterprises and self employed jobs while the remaining 40 per cent did so through wage jobs. The studies further observed that welfare changes within and between 
occupational categories were mainly channelled through an accumulation of productive assets, especially labour and employment, as well as household capital, rather than any specific increases in factor productivity. While Arbache and Page (2009) affirmed that Africa witnessed only marginal growth in-spite of its rapid growth, McMillan and Rodrik (2011) affirmed that structural change in Africa has moved in the wrong direction since the 1990 and had worked against the leveraging of good jobs, given that labour has moved from higher to lower productivity employment. On these, Page (2012) opined that Africa's slow pace of structural change mainly reflects a failure of its economies to industrialise, increasing dependence on natural resources, shrinking manufacturing sector relative to independence and an infant agro-industry and tradable services. The researcher noted that as Africa lost ground, labour moved from higher to lower productivity employment.

Nature of Structural Transformation in Nigeria. Orya (2013) averred that improvement in governance framework through multi-party democracy since 1999 and purposeful (market) reforms have redefined Nigeria's political, financial and investment hubs. The researcher affirmed that petro dollar provided investment capacity for economic diversification and higher GDP growth rate. The study further noted that Nigeria has the two building blocks for the realisation of structural transformation, that is, the resources and the market. It recommended intra-African trade, capacity building, women empowerment and integration as viable solution towards transformation. Ariyo and Olaniyan (2015) recognised the role of service sector in the emerging structural transformation in Nigeria, but noted that the structure of the Nigerian economy propelled the persistent high level of poverty and inequality. The study harped on the need to consolidate the ensuing gains from transformation in order to promote sustainable development. While, recent literature have alluded to the weak or non diversification of the Nigerian economy, given its import dependence, consumption driven and undiversified nature and the burden of poverty and unemployment (Federal Republic of Nigeria, 2017), Oyelara - Oyeyinka and Ola-David (2015) noted that the manufacturing sector has observed some improvement and that the country is undergoing a structural change of a unique sort; in addition, the proportion of those employed in agriculture has been reducing in recent years, while employment in the service sector has been on the rise. The researcher averred that the share of growth attributable to structural change increased in recent years and surpassed that attributed to within sector changes between 2005 and 2010. Specifically, the contribution of agriculture to GDP has witnessed a decrease to 23.1 per cent with the simultaneous rise in the contribution of the service sector, put at 51 per cent.

Measurement of Structural Transformation and Governance. Numerous measures of structural are evolving, however, United Nations Conference on Trade and Development (UNCTAD) (2016) established three empirical measures of structural transformation as the employment share of sector in total employment, value added by sector in total value added and the export share of sector as per cent of the gross domestic product. It however noted that the last of these measures might be misleading due to the emergence of global value chain, and as an increase in export is likely to be associated with an increase in import, given that firms import intermediary goods the production process which are later re-exported after production ceases. Given the pros and cons of these approaches, this study employed the employment share of the three key sectors (Agriculture, Industry and Services) in total employment as its measure of structural transformation.

\section{METHODS OF RESEARCH}

Study Area. Nigeria is an African Country on the Gulf of Guinea and one of the 54 countries in Africa. It consists of about 91 million hectares of land area with a population of about 170 million. It is the most populous country in Africa, largely rural and comprising about 350 ethnic nationalities. The country measures about $1,200 \mathrm{~km}$ from east to west and about $1,050 \mathrm{~km}$ from north to south, and is bounded by Cameroon to the east, Chad to the northeast, Niger to the north, Benin to the west, and the Gulf of Guinea on the Atlantic Ocean (Figure 1) to the south (Federal Ministry of Agriculture and Rural Development, 2015) . The 
federation is made up of 36 States and the Federal Capital Territory, Abuja and 776 Local Government Areas. The economy is predominantly agricultural, with the agriculture sector accounting for 23.1\% of the GDP (FMARD, 2015; Federal Republic of Nigeria, 2017), while employing 38\% of the working population (Federal Republic of Nigeria, 2017).

However, the country's economy is characterized by structural challenges that limit its ability to sustain growth, create jobs and achieve real poverty reduction (Federal Republic of Nigeria, 2016). The economy is also mono-commodity (oil) based and skewed towards consumption rather than investment, with gross domestic investment to GDP ratio of between 13 and 14 per cent. Though, the GDP rose by 6.3 per cent between 2005 and 2015, the economy entered into a recession with GDP contracting by 0.36 per cent in the first quarter, 2.1 per cent in the second quarter and 2.2 per cent in the third quarter of 2016 (Federal Republic of Nigeria, 2016). Meanwhile, oil and gas sector accounted for only 10 per cent of GDP, represented 94 per cent of export earnings and 62 per cent of government revenues (Federal and State) in 2011-2015. The source further noted that foreign exchange reserves declined from USD32 billion in January 2015 to USD25 billion in November 2016 (from a peak of USD53 billion in 2008). Arising from these developments, naira depreciated sharply, losing almost half of its value against the dollar, while foreign direct investment (FDI) declined sharply from a peak of USD8.9 billion in 2011 to USD3.1 billion in 2015(Federal Republic of Nigeria, 2016).

Sample Size and Data Collection. The study was based on secondary data and spanned 1993 - 2015. Data collected covered agriculture, industry and service sectors share of employment, real government expenditure (proxy for governance), agricultural expenditure, agricultural import and export, agricultural GDP, loan and advances, interest rate and exchange rate. Other data collected were agriculture, service and industrial sectors' contributions to GDP, export share of agriculture sector as percentage of GDP.

Analytical Techniques. Descriptive statistics were employed for the achievement of objectives 1 . This involved the generation of mean, standard deviation, graphical analysis to depict trend and coefficient of variation (CoV). The CoV was utilised to ascertain the level of variability of the agriculture, service and industrial sector share of employment. The Augmented Dickey-Fuller (ADF) unit root test was used to identify the order of integration, that is, the number of times a variable needed to be differenced to make it stationary. Cointegration model was employed to determine the long run or equilibrium relationship between variables. The Error Correction Modelling is closely bond with the concept of cointegration (Ama, 2003) and thus, was employed to reconcile the short run and long run behaviours of the economic variables in the model.

Augmented Dickey Fuller (ADF) Test. The initial step in the use of co-integration test is the need to ensure that the data proposed for data analysis are stationary. To this end, the ADF unit root test was employed to determine the order of integration of each variable, that is, the numbers of times a variable will be differenced to make it stationary.

The model was specified as follows:

$$
\Delta \mathrm{Y}_{\mathrm{t}}=\alpha+\beta_{\mathrm{t}}+{ }^{\prime} \mathrm{Y} \mathrm{Y}_{\mathrm{t}-1}+\delta_{\rho} \Delta \mathrm{Y}_{\mathrm{t}-1} \ldots \ldots \ldots+\delta_{\rho-1} \Delta \mathrm{Y}_{\mathrm{t}-\mathrm{p}+1}+\epsilon_{\mathrm{t}}
$$

Where: $\Delta=$ Change Operator; $\alpha=$ Constant; $Y_{t}=$ Variable series; $Y_{t-1}=$ Past values of variables; $\mathrm{t}=$ Time variable; $\epsilon_{\mathrm{t}}=$ White noise .

The null hypothesis that ' $Y=0$ implies the existence of a unit root in yt or that the time series is non-stationary. The three models considered are as follows:

$$
\begin{aligned}
& \Delta \mathrm{Y}_{\mathrm{t}}=\beta_{1}+\partial \mathrm{Y}_{\mathrm{t}-1}+\mathrm{a}_{\mathrm{i}}+\text { et (Intercept only) } \\
& \Delta \mathrm{Y}_{\mathrm{t}}=\beta_{1}+\beta_{2 \mathrm{t}}+\partial \mathrm{Y}_{\mathrm{t}-1}+\mathrm{a}_{\mathrm{i}}+e_{\mathrm{t}} \text { (Trend and Intercept) } \\
& \Delta \mathrm{Y}_{\mathrm{t}}=\partial \mathrm{Y}_{\mathrm{t}-1}+\mathrm{a}_{\mathrm{i}}+e_{\mathrm{t}} \text { (No intercept) }
\end{aligned}
$$

Co-integration Test. Economic theory suggests that long run relationship should exist between pair of economic or financial variables. To this end, Ljubljana (2009) noted that the framework of co-integration deals with regression with I(1) data, that is $\mathrm{I}(1)$ variables tend to diverge as $\mathrm{T}$ approaches infinity because of their unconditional variances. Numerous 
researchers further established that if two or more variables are cointegrated, they must obey an equilibrium relationship in the long run (Ama, 2003) although they may diverge substantially from that equilibrium in the short run (Ljubljana, 2009). According to Engle and Granger (1987), co-integration exist when a linear combination of a set of time series is stationary, if it is taken that the individual series are non-stationary. Ama (2003) explained that co-integration of two or more time series infers that long run or equilibrium relationship exist between them. The study further noted that for two variables to be cointegrated, the individual variables must be non-stationary, while there must be a linear combination of the non-stationary variables from a static regression involving levels of the variable which must be stationary.

Specification of the Vector Error Correction Model (VECM). Following the cointegration test, the VECM was employed to ascertain causal influence among non stationary variables and to reveal long run and individual short run relationship between the independent variables modelled and the producer price of rice, which is the dependent variable.

$$
\begin{gathered}
\Delta \mathrm{SSE}_{\mathrm{t}}=\varphi_{1}+\sum_{i=1}^{n}{ }^{{ }^{\prime}} \beta_{1 \mathrm{i}} \Delta \mathrm{AGDP}_{\mathrm{t}-1}+\sum_{i=1}^{n} 6_{1 \mathrm{i}} \Delta \mathrm{PoP}_{\mathrm{t}-1}+\sum_{i=1}^{n} 6_{1 \mathrm{i}} \Delta \mathrm{AExp}_{\mathrm{t}-1}+\sum_{i=1}^{n} 6_{1 \mathrm{i}} \Delta \mathrm{TGE}_{\mathrm{t}-} \\
{ }_{1}+\sum_{i=1}^{n} 6_{1 \mathrm{i}} \Delta \mathrm{LAD}_{\mathrm{t}-1}+\alpha \mathrm{ECT}_{\mathrm{t}-1}+\varepsilon_{\mathrm{t} .}
\end{gathered}
$$

Where: SSE - Sector share of Employment; AGDP - Agricultural Sector GDP; POP Population; AEP - Agriculture Sector Expenditure; TGE - Total Government Expenditure (Proxy for governance); LAD - Loan Advances; ECT - Error correction term; $\Delta$ - Difference in operator; $\varepsilon_{t}$ is the error term which takes care of other variables that could have structural transformation but not specified in the model, while $n$ is the optimal lag length orders of the variables.

\section{RESULTS AND DISCUSSION}

Trend of Employment Share of Agriculture and other Key Sectors of the Economy in Total Employment. The trend of employment share of key sectors (agriculture, industry and services) of the economy from 1991-2015 is presented in figure 1. The figure shows that agriculture's share of employment peaked in 1999, with $49.04 \%$ of the total share of employment, while the least of $38.45 \%$ was witnessed in 2015 . For the service sector, the highest level of employment witnessed was in 2015 with $48.82 \%$ and the minimum employment share of $37.99 \%$ in 1991 . With respect to the industrial sector, the year 1991 witnessed the peak of employment share of $14.13 \%$ and a minimum of $11.32 \%$ in 2001 . Evidence as shown by statistics and the figure shows that employment share of the agriculture sector has been declining, while that of the service sector has been witnessing simultaneous upward growth. On the other hand, the industrial sector had been static, even though, there had been an initial decline in sector share of employment between 1998 and 2009.

The mean sector share of employment is put at $45.25 \%, 42.50 \%$ and $12.24 \%$ for the agriculture, service and industrial sectors respectively (Table 1). In addition, the coefficient of variation shows that the service sector has been more volatile put at $9.10 \%$, while the industrial sector witnessed the least volatility, confirming the static nature of the trend. The general picture confirms the outcome of the works of Oyelaran-Oyeyinka and Ola-David, 2015 and Ariyo and Olaniyan, 2014 who established that Nigeria is undergoing a structural change, having noted changes in the contributions of key sector to employment. 


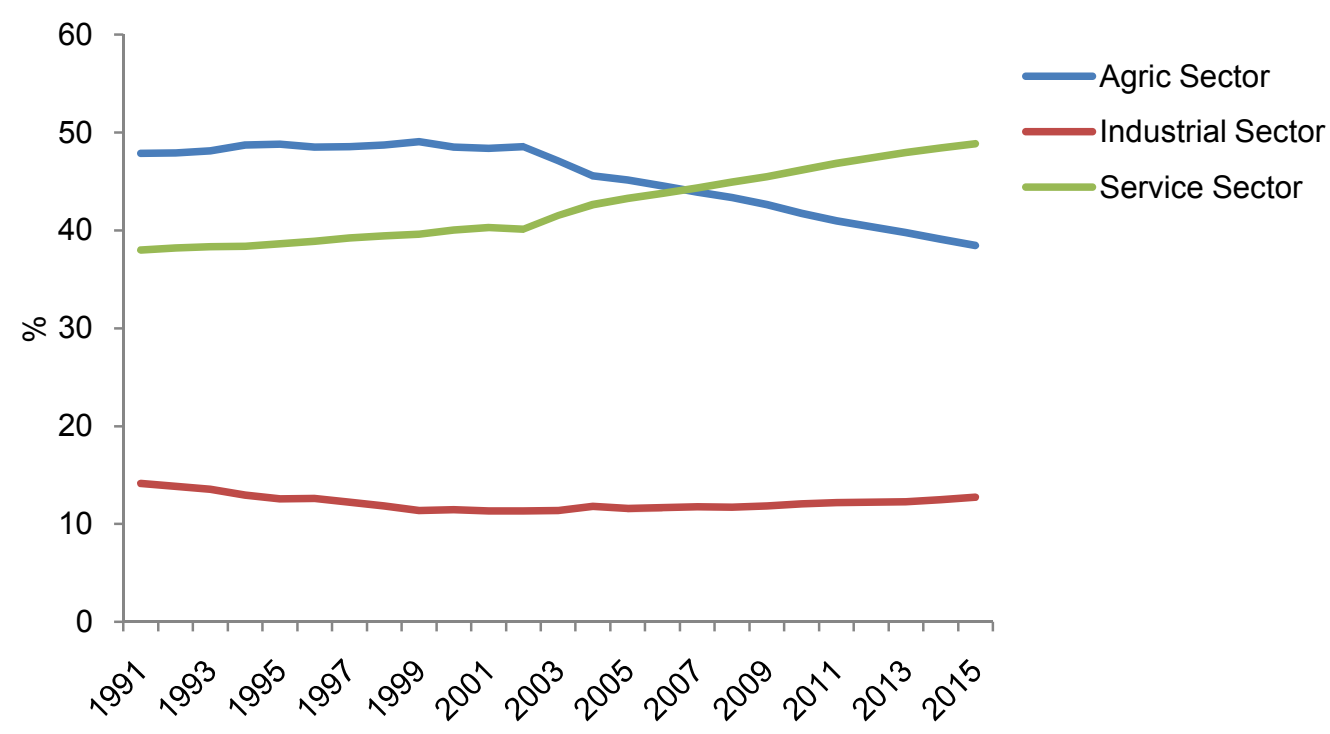

Figure 1 - Key Sector Share of Employment

Table 1 - Descriptive statistics of sector share of employment in Nigeria (1991-2015)

\begin{tabular}{cccccc}
\hline Sector & Minimum (\%) & Maximum (\%) & Standard Deviation & Mean & Coefficient of Variation (\%) \\
\hline Agriculture & 38.45 & 49.03 & 3.78 & 46.25 & 8.35 \\
Industry & 11.32 & 14.13 & 0.85 & 12.24 & 6.98 \\
Service & 37.99 & 48.82 & 3.87 & 42.5 & 9.1 \\
\hline
\end{tabular}

Source: Author's computation (2017)

Stationarity Test. The results of the stationarity test as detailed in Table 2 show that 3 variables were stationary at level, 14 variables were stationary at first differential, while another 3 variables were stationary at second differential. The results are in line with economic literature, as most economic variables are known to be stationary by the second differential. Thus, in line with the approach, variables stationary at levels were dropped, to satisfy the Johansen's assumption, while the other variables were tested for co-integration.

Table 2 - Results of Unit Root Test (Augmented-Dickey Fuller) for 1993-2015

\begin{tabular}{|c|c|c|c|c|c|}
\hline Variables & Model & $\begin{array}{l}\text { t-statistics } \\
\text { in level }\end{array}$ & $\begin{array}{c}\text { t-statistics in } \\
\text { 1st } \\
\text { difference }\end{array}$ & $\begin{array}{c}\text { t-statistics in } \\
2 n d \\
\text { difference }\end{array}$ & $\begin{array}{c}\text { Order of } \\
\text { Integration }\end{array}$ \\
\hline Employment share of Agriculture & Intercept & & $-3.482^{\star \star}$ & & $1(1)$ \\
\hline Employment share of Industry & No Intercept and trend & & $-1.998^{* *}$ & & $1(1)$ \\
\hline Employment share of Service & No Intercept and trend & & $-7.821^{*}$ & & 1(1) \\
\hline Population & Intercept & & $-3.426^{\star *}$ & & 1(1) \\
\hline Exchange Rate & No Intercept and trend & & $-2.282^{\star *}$ & & 1(1) \\
\hline GDP & Intercept & & & $-3.392^{\star \star}$ & $1(2)$ \\
\hline Agriculture Sector GDP & Intercept & & $-7.049^{*}$ & & $1(1)$ \\
\hline Service Sector GDP & No Intercept and trend & & $-2.140^{\star *}$ & & 1(1) \\
\hline Manufacturing Sector GDP & No Intercept and trend & & $-2.399 * *$ & & $1(2)$ \\
\hline Inflation Rate & No Intercept and trend & & $-2.663^{*}$ & & $1(1)$ \\
\hline Total Federal Government Exp. & Intercept & & & $-7.208^{*}$ & $1(2)$ \\
\hline Revenue & Trend \& Intercept & & $-4.674^{*}$ & & 1(1) \\
\hline Real Agriculture Expenditure & No Intercept and trend & & $-2.709^{*}$ & & $1(1)$ \\
\hline Capital Expenditure Agriculture & Intercept & & $-3.034^{* *}$ & & 1(1) \\
\hline Interest Rate & Intercept & $-3.728^{* *}$ & & & $1(0)$ \\
\hline Loan Advance & Intercept & & & $-4.405^{\star}$ & $1(2)$ \\
\hline Agriculture Sector Import & Trend \& Intercept & $-3.880^{* *}$ & & & $1(0)$ \\
\hline Agriculture Sector Export & No Intercept and trend & & $-2.534^{\star *}$ & & 1(1) \\
\hline Agriculture Trade Opening & Intercept & $-4.386^{*}$ & & & $1(0)$ \\
\hline
\end{tabular}

Source: Analysed data, 2017.

* Significant at 1 percent; ${ }^{* *}$ Significant at 5 percent. 
Johansen Co-integration Test. Arising from the outcome of the Stationarity test, Johansen test of cointegration was undertaken to ascertain whether there was long run associationship among the variables in the model. However, in view of the problems of the need to satisfy the assumptions of the Johansen test and given the step wise introduction of the variables into the model, only seven of the nineteen variables were supportive of the cointegration test. These were the employment share of agriculture (dependent variable and proxy for structural transformation in agriculture), employment share of the industry sector, employment share of the service sector, population of Nigeria, exchange rate, the gross domestic product and the agriculture sector gross domestic product. The results of the Johansen test (Table 3 ) show that the 7 variables in the equation have long run associationship, that is, they move together in the long run and that there are 5 co-integrating equations binding them. This position was double confirmed by the trace and maximum statistics. This outcome thus provides justification for the use of the Vector Error Correction Model (VECM).

Table 3 - Johansen test for cointegration

\begin{tabular}{cccccc}
\hline Maximum rank & Eigen Value & Trace Statistic & 5\% Critical Value & Max statistic & $5 \%$ Critical value \\
\hline 0 & - & 435.4526 & 124.24 & 213.9155 & 45.28 \\
1 & 0.99991 & 221.5371 & 94.15 & 91.6458 & 39.37 \\
2 & 0.9814 & 129.8913 & 68.52 & 58.7967 & 33.46 \\
3 & 0.92241 & 71.0947 & 47.21 & 35.2506 & 27.07 \\
4 & 0.78403 & 35.8441 & 29.68 & 25.4692 & 20.97 \\
5 & 0.66957 & $10.3749{ }^{*}$ & 15.41 & 9.7612 & 14.07 \\
6 & 0.34584 & 0.6137 & 3.76 & 0.6137 & 3.76 \\
7 & 0.02633 & & & & \\
\hline
\end{tabular}

Source: Analysed results, 2017.

Vector Error Correction Model Results. The results from Table 4 shows that the error correction terms for the five co-integrating equations were positive and all significant except the fourth one. The implication of this result is that there is no long run causality running from the six independent variables to employment share of agriculture, which is the dependent variable. However, given that none of the coefficients of the independent variables were significant in the equation, there was no need going further to test the short run and direction of causality for these variables. The results thus imply that is neither long run nor short run causality running from the independent variables to structural transformation in the agriculture sector in the Nigerian economy. Thus, these results questions whether there was any transformation going on in the agriculture sector in Nigeria and if so, it must have been due largely to chance or unexplained phenomenon. The results further calls to question the nature of data Nigeria's socio-economic data.

Table 4 - Vector Error Correction Model Results

\begin{tabular}{|c|c|c|c|c|}
\hline D-Price & Coefficient & Standard Error & $\bar{Z}$ & $P>Z$ \\
\hline ce 1 & 3.281212 & 1.453994 & $2.26^{\star \star}$ & 0.2024 \\
\hline ce 2 & 1.62798 & 0.6371251 & $2.56^{\star *}$ & 0.011 \\
\hline ce 3 & 3.279135 & 1.219341 & $2.69^{*}$ & 0.007 \\
\hline ce 4 & 0.8465417 & 0.5914071 & $1.43^{\mathrm{NS}}$ & 0.152 \\
\hline ce 5 & 0.115878 & 0.0041538 & $2.79^{*}$ & 0.005 \\
\hline Employagriclog & -6.791168 & 7.23281 & $-0.94^{\mathrm{NS}}$ & 0.348 \\
\hline Employindlog & -2.050144 & 2.024798 & $-1.01^{\text {NS }}$ & 0.311 \\
\hline Employservlog & -6.152593 & 6.363574 & $-0.97^{\text {NS }}$ & 0.334 \\
\hline Poplog & 2.585659 & 22.16717 & $0.12^{\mathrm{NS}}$ & 0.907 \\
\hline Excrlog & -0.0101756 & 0.0073899 & $-1.38^{\text {NS }}$ & 0.169 \\
\hline GDPLog & 0.1503457 & 0.2441611 & $0.62^{\text {NS }}$ & 0.538 \\
\hline AgrGDPLog & -0.0397995 & 0.1034297 & $-0.38^{\text {NS }}$ & 0.7 \\
\hline Constant & -0.03169 & 1.434328 & $-0.02^{\text {NS }}$ & 0.982 \\
\hline
\end{tabular}

Source: Author's Computation.

*- implies 1 percent significance; ** implies 5 percent significance. 
Diagnostic Tests. To confirm the adequacy of the data set and model used, the normality test and autocorrelation test were carried out. The output of the skewness of data ranged from -0.66 for employment in agriculture to 1.09 in employment in industry, while kurtosis ranged from -1.48 for agriculture GDP to 0.70 for employment in industry. Trochim and Donelly (2006); Gravetter and Wallnau, (2014) and Field (2009) have all affirmed that the values of skewness and kurtosis of between -2 and +2 are acceptable to prove normal univarate distribution. For the Durbin Watson test, original and transformed values of 2.06 and 2.14 were obtained respectively. Field (2009) suggest that Durbin Watson values of under 1 or more than 3 are a definite cause for concern. A rule of thumb is that test statistic values in the range of 1.5 to 2.5 are relatively normal.

\section{CONCLUSION}

Though, the data trend examined shows a decreasing share of agriculture sector in employment with a simultaneous increase in the size of the service sector share, suggesting structural change in these sectors, results from the Vector Error Correction suggested otherwise, after failing to detect causality from the independent variables in the model to the dependent variable (proxy of structural change in agriculture). The outcome of this study thus raises questions as to whether the transformation observed through trend data was due to chance. While suggesting further work to ascertain the true position of transformation in the agriculture sector and its determinants, we are of the opinion that to sustain the transformation trend in the sector, there is need for increased technological change, enhanced specialization and trade and increased efficiency, complemented by improvement in human capita and institutions within the agriculture sector.

\section{REFERENCES}

1. Arbache, J.S. and Page, J. (2009). "How Fragile Is Africa's Recent Growth?" Journal of African Economies 19: 1-24.

2. Ariyo, A. and Olaniyan, O. (2015). Structural Transformation and Inequality: Evidence from Nigeria. Springer Vol. 57, Issue 3-4, pp 531-539.

3. Badiane, O. (2013). Agriculture and Structural Transformation in Africa. International Food Policy Research Institute.

4. Christiaensen, L. and Kaminski, J. (2015). Structural Change, economic growth and poverty reduction-Micro evidence from Uganda, Working Paper Series No 229, African Development Bank, Abidjan, Cote d' Ivoire.

5. Field, A.P (2009). Discovering statistics using SPSS: and drugs and rock ' $n$ ' roll (3rd edition). London: Sage.

6. Gravetter, F. and L. Wallnau (2014), Essentials of Statistics for the Behavioural Sciences (8th edition) Belmont, CA: Wadsworth.

7. McMillan, Margaret and Dani Rodrik, "Globalization, Structural Change and Productivity Growth" Washington, DC: IFPRI (processed).

8. Mensah, J.T. (2016). What Drives Structural Transformation in Sub-Saharan Africa? African Development Review Vol. 28 No. 2.

9. Norton, G.W., Alwang, J. and Masters, W.A. (2015). Economics of Agricultural Development. World Food Systems and Resource Use. Routledge, Taylor and Francis Group, London and New York.

10. Orya, R. (2013). Structural Transformation in Nigeria and Africa. http://www.vanguardngr.com/2013/06/structural-transformation-in-nigeria-and-africa/

11. Oyelara-Oyeyinka, O. and Ola-David, O. (2015). Structural Transformation in Nigeria: Steering Foreign Direct Investment towards Inclusive Growth

12. Page, J. (2012). Youth, Jobs and Structural Change: Confronting Africa's "Employment Problem" African Development Bank's Working Paper Series. No 155, October. Africa Development Bank. 
13. Simplice, A. (2015). ReaseachGate Post. What are the variables to proxy governance? ResearchGate Professional Network. https://www.researchgate.net/post/

14. Trochim, W.M. and J.P. Donnelly (2006), The research methods Knowledge Base (3rd Edition) Cincinnnati, $\mathrm{OH}$.

15. United Nations Conference on Trade and Development (UNCTAD), (2016). The Structural Transformation Process: trends, theory and empirical findings. UNCTAD Teaching Materials- Virtual Institute.

16. United Nations Economic Commission for Africa, (2016). Macroeconomic Policy and Structural Transformation of African Economies. Addis Ababa, Ethiopia.

17. United Nations Educational Scientific and Cultural Organization (undated). Concept of Governance. http://www.unesco.org/new/en/education/themes/strengthening-educationsystems/quality-framework/technical-notes/concept-of-governance/

18. World Bank, (2009). Global Monitoring Report 2009. A Development Emergency. Washington D.C., United States of America. 